\title{
Dietary supplement use among academic pharmacists
}

Michael S. MURPHY, Albert I. WERTHEIMER, Elaine D. MACKOWIAK.

\begin{abstract}
*
United States sales of dietary supplements exceeded $\$ 18$ billion in 2002, indicating that dietary supplement use is common among the American public. This report describes a survey of academic pharmacists and their use of dietary supplements and herbs. To date, most data comes from retail or community pharmacists, so a survey was developed to collect information regarding dietary supplement and herb usage from academic pharmacists. Academic pharmacists are probably the most knowledgeable group in regards to assessing the clinical value of supplements.

Our results showed that $54 \%$ of academic pharmacists have used dietary supplements or herbs. However, it is interesting to note that most of the dietary supplements listed were not in the top ten most commonly used supplements. In addition, there was no excessive use of supplements or herbs by this group of pharmacists since the majority of respondents listed multivitamins.
\end{abstract}

Keywords: Medicine, Herbal. Dietary Supplements. utilization. Faculty. Pharmacists. United States.

\footnotetext{
*Michael S. MURPHY. PharmD. Candidate. Temple University School of Pharmacy. Philadelphia PA (USA). Albert I. WERTHEIMER. PhD, MBA. Department of Pharmacy Practice. Temple University School of Pharmacy. Philadelphia PA (USA).

Elaine D. MACKOWIAK. PhD. Department of Pharmacy Practice. Temple University School of Pharmacy. Philadelphia PA (USA).
}

\begin{abstract}
RESUMEN
Las ventas en Estados Unidos de suplementos dietéticos superan los 18.000 millones de dólares, lo que indica que el use de suplementos dietéticas es común entre el público americano. Este informe describe una encuesta a farmacéuticos académicos y su uso de suplementos dietéticas y plantas medicinales. Hasta la fecha, la mayoría de los datos vienen de farmacias comunitarias o de detallistas, por lo que se desarrolló una encuesta para recoger información sobre e luso de suplementos dietéticas y plantas medicinales por los farmacéuticos académicos. Los farmacéuticos académicos son probablemente el grupo más reconocido para evaluar el valor clínico del os suplementos. Nuestros resultados muestran que el $54 \%$ del os farmacéuticos académicos ha usado suplementos dietéticos o plantas medicinales. Sin embargo, es interesante referir que la mayoría de los suplementos dietéticas listados no aparecen entre los 10 más comúnmente utilizados. Además, no hubo excesiva utilización de suplementos o plantas medicinales en este grupo de farmacéuticos ya que la mayoría de los respondentes relató multivitamínicos.
\end{abstract}

Palabras clave: Plantas medicinales. Suplementos dietéticos. Académicos. Farmacéuticos. Estados Unidos.

\section{(English)}

\section{INTRODUCTION}

Dietary supplement and complementary medicine use is common among the American public. ${ }^{1}$ It is estimated that $35 \%$ of adults regularly use dietary supplements and sales of these supplements exceeded $\$ 18$ billion in $2002 .^{2}$ This is approximately $\$ 200$ per year, per person expenditure for these dietary supplements in the United States.

In addition, many people believe that herbs and other dietary substances are approved by the Food and Drug Administration (FDA) and would not be sold unless they were safe and effective. ${ }^{1}$ Dietary supplements are regulated by the Dietary Supplement Health and Education Act (DSHEA) of 1994, which assumes that they are safe and effective as claimed. ${ }^{1}$ DSHEA also limits the control that the FDA can exert over dietary supplements to ensure product safety. ${ }^{1}$ Consumers who read the labels of dietary supplements carefully will find the 
following disclaimer, "These statements (i.e., referring to safety and efficacy) have not been evaluated by the FDA. This product is not intended to diagnose, treat, cure or prevent any disease."

Many people believe dietary supplements are held to the same standards as over the counter medications. ${ }^{1}$ In addition, $68 \%$ believe that warning labels are required, and $55 \%$ believe there is scientific support for the safety and efficacy claims for each product. ${ }^{1}$ These responses show that much of the public is unaware of the lack of regulation in the dietary supplement market, and how it differs from the prescription and non-prescription market. There is still no generally accepted process to assure that the supplement contains what it states on the label.

Furthermore, dietary supplements can contain active ingredients and inactive ingredients that are capable of producing adverse drug events. ${ }^{1}$ These adverse drug events can be due to interactions with prescription medications, over the counter medications, other supplements, or concomitant health conditions of the patient. ${ }^{1}$

The recent surge in dietary supplement sales seems to be driven by two segments: dieters and the baby boomers. ${ }^{3}$ The recent diet trends over the past several years have increased sales of various products including TrimSpa and Hydroxycut by MuscleTech. $^{3}$ In addition, there is Metabolife, Hoodia 911, Zantrex 3, and Stacker 3. Even with the removal of products containing ephedra, diet aids were big sellers. ${ }^{3}$ In addition, the baby boomers favored products such as glucosamine and chondroitin for their aching joints. ${ }^{3}$ Fish oil is popular for heart health and CoQ10 was another big seller. $^{3}$

Many consumers purchase these products at their local pharmacies and may ask pharmacists questions about different products. Although a majority of pharmacists have reported taking dietary supplements, fewer than half of pharmacists, $40 \%$, reported recommending dietary supplements to a patient. $^{4}$ However, personal use of dietary supplements by a pharmacist correlated with a twofold increase in the likelihood of a recommendation to a patient. ${ }^{4}$

\section{METHODS}

This report describes a survey that was designed to evaluate the prevalence of use, as well as the different types of dietary supplements and complementary medicines used. This survey was conducted to collect information about academic pharmacists' use of dietary supplements and herbs. Since most of the current information about use of dietary supplements and herbs comes from pharmacists in the retail or community environment, it would be interesting to see what was used by pharmacists in academia. Therefore, a convenience sample from the 90 schools of pharmacy in the United States was used by sending a survey to all the pharmacy practice department chairpersons. The survey was mailed in December 2005 and responses were collected through February 2006.
The survey collected information regarding the respondents' state of health, the different types of dietary supplements or complementary medicine used, the effects experienced, consideration of future use, and whether they would recommend usage of these products to others. The survey also collected their opinions on whether these dietary supplements and complementary medicines should be more rigorously regulated by the Food and Drug Administration (FDA).

\section{RESULTS}

Forty one responses were collected from the 90 United States pharmacy schools listed in the "Roster of Faculty and Professional Staff" from the American Association of Colleges of Pharmacy. ${ }^{5}$ Out of the 41 responses, $31(76 \%)$ were male, 6 were female $(15 \%)$, and $4(9 \%)$ were unknown. This sample is not representative of pharmacists due to the low number of women in the study. Also, women are more likely to use medications than men. Of those who responded, $17(41 \%)$ were between the ages of 41-50 years old; 14 (34\%) were between 51-60 years old; 5 (12\%) were between $31-40$ years old and $5(12 \%)$ were > 60 years old. The number of respondents indicating that their current state of health was excellent was 25 (61\%); good $13(32 \%)$; and fair $2(5 \%)$. No respondents indicated poor health. Therefore, the majority of the respondents had no major health conditions, good nutrition habits, and were physically active.

Overall, 22 (54\%) of 41 respondents indicated they have taken dietary supplements. Nineteen (46\%) of 41 respondents indicated they have not taken dietary supplements. Currently, 16 respondents indicated they take dietary supplements or herbs now, while 20 respondents indicated they currently do not take dietary supplements or herbs. Several respondents indicated taking dietary supplements in the past, but they did not mark an answer for current use and this accounted for the slight difference between overall users and current users.

The types of dietary supplements taken was quite varied, however, the top 4 most common types were: (\# of respondents in parentheses)
1. Multivitamins (15)
2. Glucosamine (4)
3. Folic Acid (3)
3. Omega-3 Oil/Fish Oil (3)
4. Multi-mineral supplement (2)
4. Melatonin (2)
4. Selenium (2)
4. Vitamin C (2)

When asked whether any of the proposed effects of the dietary supplements or herbs were experienced, $13(59 \%)$ responded yes, $4(18 \%)$ responded no, and $5(23 \%)$ did not respond out of the 22 respondents who indicated that they had taken dietary supplements. None of the respondents who had taken dietary supplements or herbs indicated that any adverse effects were experienced. Among the effects that were experienced, some of those listed included: glucosamine - less bone/joint pain; 
ginseng - strength increased; and vitamins increased energy. Most of the current dietary supplement users indicated their primary care physician was aware of their supplement use, 17 of $18(94 \%)$.

Twenty out of 41 respondents (49\%) indicated that family members had also used dietary supplements. The most common supplements used were multivitamins 14 (70\%), and glucosamine, 5 (25\%). Some others listed included black cohosh, creatine, saw palmetto, and melatonin. Thirteen (65\%) respondents indicated that the proposed effects were experienced. None indicated any adverse effects were experienced. Of the family members whose use was reported, 17 out of $20(85 \%)$ indicated that their primary care physicians were aware of their use.
The respondents were also asked whether they would consider using dietary supplements or complementary medicine in the future. Twenty-nine (71\%) would consider using them. In addition, a majority of the respondents, 27 of $41(66 \%)$, would recommend dietary supplements or complementary medicine to others.

Furthermore, the respondents were asked how they would feel about these products being regulated by the FDA. The respondents were asked to choose the answer that most closely represented their opinion. A large majority of the respondents, $81 \%$, feel that regulation by the FDA would be beneficial. Another $12 \%$ feel that FDA regulation would be OK, as long as the products were still available for sale. Only $5 \%$ feel that FDA regulation is not necessary. One respondent did not answer this question.

\begin{tabular}{|c|c|c|}
\hline 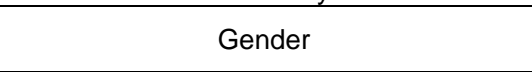 & $\begin{array}{l}31 \text { Males } \\
6 \text { Females }\end{array}$ & (4 unknown) \\
\hline $\begin{array}{l}\text { Age } \\
31-40 \\
41-50 \\
51-60 \\
>60\end{array}$ & $\begin{array}{c}5 \\
17 \\
14 \\
5\end{array}$ & \\
\hline $\begin{array}{l}\text { Health } \\
\text { Excellent health } \\
\text { Good health } \\
\text { Fair health } \\
\text { Average health } \\
\text { Poor health }\end{array}$ & $\begin{array}{l}25 \\
13 \\
2 \\
0 \\
0\end{array}$ & \\
\hline $\begin{array}{l}\text { Have taken dietary supplements or } \\
\text { complementary medicine in the past }\end{array}$ & 22 & \\
\hline $\begin{array}{l}\text { Have not taken dietary supplements or } \\
\text { complementary medicine in the past }\end{array}$ & 19 & \\
\hline $\begin{array}{l}\text { Types of supplements } \\
\text { Multivitamin } \\
\text { Glucosamine } \\
\text { Folic Acid } \\
\text { Omega-3 Oil/Fish Oil } \\
\text { Multi-mineral supplement } \\
\text { Melatonin } \\
\text { Selenium } \\
\text { Vitamin C }\end{array}$ & $\begin{array}{l}15 \\
4 \\
3 \\
3 \\
2 \\
2 \\
2 \\
2\end{array}$ & $\begin{array}{l}\text { Other Supplements } \\
\text { Acidophilus } \\
\text { Calcium } \\
\text { Echinacae } \\
\text { Ginseng } \\
\text { Ginger root } \\
\text { Prenatal Multivitamin } \\
\text { Thera-tears Capsules } \\
\text { Women's Once-a-day }\end{array}$ \\
\hline $\begin{array}{l}\text { Effects } \\
\text { Experienced Proposed Effects of } \\
\text { supplement } \\
\text { Did not experience proposed effects of } \\
\text { supplement }\end{array}$ & 13 & $\begin{array}{l}\text { Effects Listed } \\
\text { less bone/joint pain (Glucosamine) } \\
\text { strength increased (Ginseng) } \\
\text { increased energy (multivitamin) } \\
\text { extra folic acid to prevent birth defects (prenatal vitamins) } \\
\text { preventative effects (Oscal, Women's Once-a-day) } \\
\text { these substances do not produce effects that are acutely } \\
\text { observable (Multivitamin w/ minerals, Vitamin E, } \\
\text { Selenium) } \\
\text { assumed met RDA for vitamins (multivitamin) }\end{array}$ \\
\hline Experienced unintended effects & 0 & \\
\hline $\begin{array}{l}\text { Primary Care } \\
\text { supplement use }\end{array}$ & 17 & \\
\hline $\begin{array}{l}\text { Family members also used dietary } \\
\text { supplements or complementary medicine }\end{array}$ & 20 & \\
\hline $\begin{array}{l}\text { FDA Regulation } \\
\text { FDA regulation beneficial } \\
\text { FDA regulation OK as long as products } \\
\text { still available for sale } \\
\text { FDA regulation not necessary }\end{array}$ & $\begin{array}{c}33 \\
5 \\
2\end{array}$ & (1 did not respond) \\
\hline
\end{tabular}




\section{DISCUSSION}

As a result of this pilot study survey, it appears that there is no overuse of dietary supplements by the department chairs at the various pharmacy schools throughout the United States. The most common dietary supplements used were multivitamins, followed by glucosamine. Many of the respondents indicated good or excellent health which would correspond to less use of dietary supplements or complementary medicine for various treatment or preventative reasons. This would explain why many of the most common dietary supplements were not reported. A few that were reported include ginseng, melatonin, echinacea, omega-3 oil, and ginger root. Voelker reported in JAMA, that the top 10 natural products are: 1. echinacea, 2. ginseng, 3. ginko biloba, 4. garlic, 5. glucosamine, 6. st. john's wort, 7. peppermint, 8. fish oil/omega-3, 9. ginger, and 10. soy supplements. ${ }^{6}$ In addition, the fact that many were not used may imply something about academic pharmacists' faith in some of these supplements.

Our results also show that 17 out of the 22 respondents $(77 \%)$ who indicated that they had taken dietary supplements were between the ages of 41 and 60 years old. However, this also corresponds to the distribution of the ages for those who responded to the survey since $75 \%$ of the respondents overall were in that same age range. So, we cannot correlate use to a certain age range in this survey.

Comparable to the rest of the healthcare community, a large majority of our respondents indicated they would like to see more regulation by the FDA. A strong concern throughout healthcare, in general, is that current DSHEA allows dietary supplements to be sold with minimal or vague labeling, no standard ingredients, and a lack of current good manufacturing processes (cGMPs). ${ }^{7}$ As a result, these supplements could be made in an unsanitary area with contaminated ingredients, be labeled with unsubstantiated claims, or even contain none of the labeled ingredients. ${ }^{7}$ This creates several legal and ethical issues for pharmacists. Due to the lack of regulation, we cannot ensure the safe and effective use of these supplements. However, they are sold in pharmacies where their presence is given a cachet of respectability. Furthermore, pharmacists have a professional obligation to counsel when patients desire a consultation. In the best interest of patient care, the regulations need to be revised to assure purity, safety, and efficacy of these supplements. ${ }^{7}$

Within the DSHEA of 1994, there was a provision for the FDA to enact cGMPs for dietary supplements. $^{8}$ These provisions were to be modeled after the cGMPs for food. Also, the cGMPs could only impose standards for which there is a current and generally available analytical methodology. The enactment of cGMPs would help ensure that the companies manufacturing or marketing the supplements are not adulterating or misbranding the supplements. These cGMPs would also help ensure the consumer that the supplement they are buying contains what the label says it does, including the quantity of different ingredients and the product's purity. ${ }^{8}$

So, with this provision available in DSHEA, the FDA requested an outline from dietary supplement industry representatives on the cGMPs for dietary supplements in November of $1995 .^{\circ}$ Upon the FDA's review of the outline, they felt certain things were missing from the outline and that some groups did not have a chance to give input on these cGMPs such as the health care community and consumers. As a result, the FDA issued an advance notice of proposed rulemaking in the Federal Register in February of 1997. Then in 1999, they held several public meetings to collect stakeholder comments on the development of an overall strategy. FDA staff also toured several manufacturing facilities of dietary supplements to learn more about the industry which could help them while developing the cGMP's. After the many years of preparing how to develop these regulations and obtaining information about the dietary supplement industry, the FDA proposed a rule on March 13, 2003 in the Federal Register. After an extended comment period, there were 2 public meetings, one on each coast of the U.S., to provide clarification on the proposed rule and explain how to submit comments about the rule. Furthermore, there was a satellite broadcast meeting on the proposed rule in May of $2003 .^{8}$

As it stands now, the satellite broadcast meeting on the proposed rule in May of 2003 is the last documented action on this proposed rule regarding cGMPs of dietary supplements according to the FDA webpage.

Although progress is being made on increasing the regulation of dietary supplements, an example of why it is important to the healthcare community is that testimonials from celebrities and large marketing campaigns can significantly influence consumers to use certain dietary supplements. The most recent dietary supplement craze was "Airborne" for cough and cold prevention. ${ }^{9}$ This concoction was developed by an ex-second grade teacher from California in her kitchen. Supported by venture capital and a $\$ 10$ million dollar advertising campaign, this dietary supplement expects revenues over $\$ 120$ million for this year. In some markets, this product has even outsold Sudafed or Tylenol Cold tablets. Basically, this tablet is a mega-dose of vitamins with echinacea. The recommended dosage originally on the package was one tablet "every three hours." However, it was recently changed to add "up to three times per day as necessary," because the 15,000 units of vitamin A from three tablets is enough to cause possible liver damage, dizziness, and blurred vision. Although none of the ingredients have been scientifically proven to prevent colds, the chief executive, Elise Donahue, states that there is no need for further scientific research on Airborne's effect on health because "We have letters from over 40,000 consumers a year saying they swear by it."

There is probably no group in the United States more knowledgeable than academic pharmacists as to the possible clinical value of supplements and yet we find that $54 \%$ of the respondents to this survey 
indicated they had taken dietary supplements or herbs. Since pharmacists, like all other persons sometimes rely on beliefs and make decisions based on hopes, it should not be any surprise that the lay public are, on average, huge consumers of these products. Although this survey was a preliminary study of academic pharmacists, this could indicate the need for a larger more diverse study. Since this survey mostly had respondents using multivitamins, a future study could be done to see whether there are any correlations between the types of dietary supplements or herbs used and the number of well supported studies for these different types of dietary supplements or herbs.

\section{References}

1. Morrow JD, Edeki TI, El Mouelhi M, Galinsky RE, Kovelesky R, Noveck RJ, Preuss C; American Society for Clinical Pharmacology and Therapeutics. American Society for Clinical Pharmacology and Therapeutics Position Statement on Dietary Supplement Safety and Regulation. Clin Pharmacol Ther 2005;77(3):113-22.

2. National Academy of Sciences. Dietary Supplements: A Framework for Evaluating Safety. Washington DC. 2004, pg. 19.

3. Johnsen M. Dieters, Baby Boomers Drive Supplement Sales. Drug Store News 2004;June 21.

4. Howard N, Tsourounis C, Kapusnik-Uner J. Dietary Supplement Survey of Pharmacists: Personal and Professional Practices. J Altern Complement Med. 2001;7(6):667-80.

5. American Association of Colleges of Pharmacy. Roster of Faculty and Professional Staff 2004-2005. Alexandria, VA, September 2004.

6. Voelker R. IOM Points to Need for More Research, Regulation in Alternative Medicine. JAMA 2005;293(10):1178-80.

7. Chavis LM. Pharmacy-based Consulting on Dietary Supplements. J Am Pharm Assoc 2001;41(2):181-91.

8. FDA/CFSAN Dietary Supplements: Industry Information and Regulations. http://www.cfsan.fda.gov/ dms/dsind.html\#GMPS, (accessed 10-11-2006).

9. Linden D. Nothing to Sneeze At. Forbes 2006;(March 13):41. 